\title{
The dynamics of pine marten predation on red and grey squirrels
}

\author{
Joshua P. Twining ${ }^{1} \cdot$ W. Ian Montgomery ${ }^{1} \cdot$ David G. Tosh $^{2}$ \\ Received: 12 October 2019 / Accepted: 3 April 2020 / Published online: 28 April 2020 \\ (c) The Author(s) 2020
}

\begin{abstract}
Invasive alien species pose one of the greatest threats to global biodiversity. In parts of Europe, introduced eastern grey squirrels (Sciurus carolinensis) have caused regional extinctions of the native red squirrel (Sciurus vulgaris). However, exposure to pine martens (Martes martes) has been demonstrated to reverse the competitive outcome between red and grey squirrels. The mechanism whereby this effect occurs remains unclear. It is hypothesised that direct predation, facilitated by a lack of behavioural response, is the mechanism driving this relationship. We review the literature and reanalyse a new dataset to provide further data on the occurrence of both squirrel species in the scats of pine marten. Both squirrel species occurred in the scats of pine marten confirming its role as a predator of these species. Predation of grey squirrels was significantly higher than red squirrels and was recorded only in spring and summer. Our review provides evidence for the mechanism driving the current decline in grey squirrels in Ireland and Scotland and supports the hypothesis that in the presence of a shared predator, direct predation influences the outcome of species interactions between native red and non-native grey squirrels.
\end{abstract}

Keywords Pine marten $\cdot$ Diet $\cdot$ Grey squirrel $\cdot$ Red squirrel $\cdot$ Predation $\cdot$ Invasive species $\cdot$ Prey switching

\section{Introduction}

Invasive alien species (IAS) arise when non-native species become established in a new environment and negatively impact the naive ecosystem. Impacts by IAS on native biodiversity, to which IAS are a global threat (ISAC 2006), have been widely reported. Awareness, and the ability to measure impacts, of IAS on economies, health and ecosystem services is increasingly being recognised and documented (Charles and Dukes 2008; Kelly et al. 2013; Pimental et al. 2000). The annual economic cost of IAS to Europe in 2009 was estimated at $€ 12$ billion p. a. (Kettunen et al. 2009), a

Handling editor: Raquel Monclús.

Joshua P. Twining

joshuaptwining@gmail.com

W. Ian Montgomery

i.montgomery@qub.ac.uk

David G. Tosh

david.tosh@nnmi.com

1 School of Biological Sciences, Queen's University of Belfast, 17 Chlorine Gardens, Belfast BT9 5AJ, Northern Ireland, UK

2 National Museums Northern Ireland, 153 Bangor Road, Holywood BT18 0EU, Northern Ireland, UK cost that has likely increased due to continued increases of many IAS. Mitigation of these losses can take the form of direct culling (e.g. Schuchert et al. 2014), the use of poisons (Witmer et al. 2007) or biocontrol via the introduction of a predator (Lindquist et al. 1992) or a pathogen (Cooke and Fenner 2002). The introduction of disease or predators from the native range of an IAS (Simberloff and Stiling 1996; Shine 2010) may lead to unintended negative consequences, e.g. the development of resistance or predation on non-target species (Hays and Conant 2007; O'Donnell et al. 2017).

One IAS of widespread concern in Europe is the eastern grey squirrel (Sciurus carolinensis). Introduced from North America to Great Britain and Ireland in the nineteeth and twentieth centuries (Lloyd 1968), it is now in Italy where its presence poses a risk to the rest of continental Europe (Bertolino et al. 2014). The species negatively impacts forestry (Mayle and Broome 2013) and native biodiversity (Hewson and Fuller 2003; Newson et al. 2010), particularly the red squirrel which has been replaced across much of its former range in Britain (Lloyd 1968). Replacement of red by grey squirrels is due to factors including: larger individual mass and greater population densities of grey squirrels; decreases in red squirrel fecundity, residency and recruitment (Wauters and Gurnell 1999; Gurnell et al. 2004). Recent research suggests that alterations to microparasite communities (Romeo 
et al. 2015) and personality (Wauters et al. 2019) in red squirrels during co-occurrence may also play a role. However, the most important factor remains grey squirrels acting as a vector for squirrel pox virus (SQPV) causing mortality in red, but not grey squirrels (Tompkins et al. 2003; Rushton et al. 2006). In order to prevent a repeat of this situation in Italy and continental Europe, efforts are required to manage or eradicate grey squirrels [Regulation (EU) 1143/2014].

Control of the grey squirrel has been attempted in Britain and Ireland via culling to mitigate their impacts. However, success has been localised and arguably ineffective, with few successful outcomes (Schuchert et al. 2014). Cost and effort required impedes successful control both locally and nationally in Great Britain and Ireland (Manchester and Bullock 2001), whilst in Italy, objections by animal rights groups have hindered control efforts (Genovesi and Bertolini 2001; Lioy et al. 2019). At present, culling is the only means available to control grey squirrels as efforts to develop an immuno-contraceptive for grey squirrels continue with no practical and deliverable method yet available (Barr et al. 2002). Consequently, a new approach is needed to provide effective control of the grey squirrel in European landscapes, reducing their economic cost $(>£ 10$ million per annum in Britain alone, Mayle and Broome 2013) and reversing their replacement of the native red squirrel.

The recent research suggests a potential new approach to control grey squirrels may involve a recovering native predator, the European pine marten (Martes martes). Negative, spatial correlations between pine marten and the presence of grey squirrels has been recorded in Ireland (Sheehy and Lawton 2014) and Scotland (Sheehy et al. 2018). The latter suggests exposure to pine martens negatively impacts grey, but not red squirrel occupancy (Sheehy et al. 2018) and that exposure to pine martens reverses the typical outcome of resource and disease mediated competition between the two sciurids. The recent research has demonstrated that native red squirrels possess anti-predator behaviours to pine martens, while invasive grey squirrels do not (Twining et al. 2020). This suggests behavioural differences may enable the red squirrel to avoid pine martens more successfully than greys which, as a result, are more vulnerable to predation by pine martens than red squirrels.

The European pine marten is an opportunistic omnivore which since its legal protection under the 1976 Irish Wildlife Act and the 1981 Wildlife and Countryside Act, has been recovering in the British Isles. Its recent recovery in Ireland and Britain is particularly interesting due to the fact the species is a woodland specialist, recovering in a landscape that is lacking in suitable habitat: woodland. The pine marten's ability to do so has recently been linked to its dietary plasticity and proficiency for prey switching (Twining et al. 2019). Seasonal prey switching in response to abundance and vulnerability of resources may explain how pine marten recovery could have the observed effect of causing declines in grey squirrel populations (Sheehy and Lawton 2014; Sheehy et al. 2018; Flaherty and Lawton 2019), without squirrels being a frequently recorded item in the diet. Most dietary studies on pine marten either focus on single field sites or sampling periods (Helldin 2000; Lynch and McCann 2007; Zalewski 2007; Sheehy et al. 2013; O’Meara et al. 2014). The pine martens arboreality means it is the only mammalian predator in Ireland and Britain capable of targeting squirrels in their dreys. It may have a strong ability, therefore, to regulate prey populations lacking refugium from predation (Menge and Sutherland 1976).

In order to investigate the potential mechanism for the reversal of squirrel replacement, we reviewed published studies to compile available information on the occurrence of red and grey squirrels in the diet of the European pine marten, and reanalysed Twining et al. (2019), a new dataset of 918 scats. These were collected from twenty sites across the pine martens range in Northern Ireland accounting for the presence of red and grey squirrels at each site (Tosh 2015). We aim to determine whether there is evidence for pine marten predation to be a potential mechanism for the observed reversal of the replacement of red squirrels by grey squirrels in Britain and Ireland (Sheehy and Lawton 2014; Sheehy et al. 2018; Flaherty and Lawton 2019), and to highlight potential nuances in squirrel predation by the pine marten elsewhere in Europe.

\section{Methods}

Peer reviewed and unpublished literature on European pine marten diet was searched for via the Web of Science and Google Scholar. Searches conducted utilised the terms "pine marten diet squirrel", "pine marten predation squirrel". Publications were selected using the following criteria: (1) diet composition was estimated by analysis of scats with a minimum sample size of 100; (2) results were reported for each prey species as frequency of occurrence (FO \%), or as number of times an item occurred and total sample size number to FO \% could be calculated manually and (3) red or grey squirrels, or both species, were reported present in the study area or diet. In addition, we supplement the review material by using data from Twining et al. (2019) accounting for the presence of either squirrel species at the study sites. In the latter study, twenty sites were selected in which to collect scats and investigate pine marten diet (Twining et al. 2019) based on the data from a previous survey examining the distribution of the squirrel species and the pine marten in Northern Ireland (Tosh 2015). $3 \mathrm{~km}$ transects were established at each of the twenty study sites. All sites were visited once per month for 12 months and on the first visit, all scats were cleared. Subsequently, only fresh scats deemed 
of the correct shape (e.g. heart or C-shaped) and smell (e.g. pungent, aromatic) typical of pine martens were collected (Lynch and McCann 2007; Twining et al. 2019). Scats were stored in sample bags with self-indicating silica gel to dry out samples. Developments in methods using mitochondrial DNA to assign species to scats (O'Reilly et al. 2007; Velli et al. 2019) has enabled some recent studies to make use of genetic techniques to determine species producing scats (Caryl et al. 2012). However, the current high costs of this method can be prohibitive to adoption of such an approach and many studies use alternative methods. Twining et al. (2019) used a multi-evidence approach, confirming the presence of pine martens at sites using camera traps followed by scat collection by a single trained fieldworker using a scoring system, with all scats in doubt being discarded. Further details and discussion of scat identification method is available in Twining et al. (2019).

Due to the scarcity of locations where pine marten and grey squirrel co-occur in Ireland (Sheehy and Lawton 2014; Tosh 2015; Flaherty and Lawton 2019), there is an unavoidable bias towards sites supporting only red squirrels. Sites included coniferous plantation, coniferous plantation and heath, deciduous forest, and mixed broadleaf and coniferous habitats.

Dry macro-analysis of scats was conducted to establish diet. Mammal hairs were identified to species level via examination of guard hair cuticle scales and medulla patterns at $10 \times$ and $40 \times$ magnification (Teerink 1991). Data are reported as frequency of occurrence (FO \%) for comparison to previous dietary studies (Klare et al. 2011). Frequency of occurrence was calculated as

FO $\%=\frac{\text { Number of times prey item present }}{\text { Total number of scats }} \times 100$

Pearson's Chi squared test was used to test for general effects of season on proportions of red and grey squirrel in the scats. Fisher's Exact tests (FET) were used to compare proportions of grey and red squirrels in scats between seasons. Seasons were categorised using the meteorological Northern hemisphere definitions, i.e. Winter (Dec-Feb), Spring (Mar-May), Summer (June-August) and Autumn (Sept-Nov). All statistical tests were carried out in R. 3.2.1 (R Core Team 2014).

\section{Results}

The literature review revealed 13 publications (Table 1) in addition to Twining et al. (2019) that met the criteria above. Squirrel predation (grey or red) was recorded in $10(76.9 \%)$ of the 13 publications (Table 1). Red squirrels were recorded as being present at the study sites of all 13 publications and occurred in the diet in 9 of these $(69.2 \%$ of investigations where the species co-occurred with the pine marten). In contrast, grey squirrels were present in 1 of the 13 study sites as well as Twining et al. (2019), where they were also present in the diet $(100 \%$ of investigations where the species co-occurred with the pine marten; Table 1). Overall, squirrel predation was highly variable, but typically low or absent for red squirrels with occurrence ranging from 0 to $19.0 \%$ (mean $=3.7 \%$ ). The only study with occurrence of grey squirrels available to review had a significantly higher frequency of occurrence at $15.6 \%$ (Table 1). Despite low averages, there are rare examples of elevated predation rates on red squirrels, e.g. FO $\%=50.1 \%$, Storch et al. (1990); FO $\%=11.5 \%$, Pulliainen and Ollinmaki (1996). Both these studies were conducted during winters in boreal forests.

Year-round, seasonal data are scarce (Table 2). Only two published studies present data divided into four seasons, and neither study reports squirrel present in the diet (Sidorovich et al. 2005; Caryl et al. 2012). There is only one study with grey squirrels present in the studies reviewed, highlighting the scarcity of data on the occurrence of grey squirrels in pine marten diet when the species co-occur (Sheehy et al. 2013).

We re-examined data from Northern Ireland available from Twining et al. (2019). The investigation reported a total of 918 pine marten scats collected over 12 months, of which 763 were collected from the 15 red only sites, 48 from the two grey only sites and 107 from the two red and grey squirrel sites. These were red squirrel resident sites, but grey squirrels turned up in the scats, representing likely transient individuals. When we only considered pine marten scats from sites with either red or grey squirrels present (as confirmed by camera traps and presence of hair in the scats), grey squirrels had a mean frequency of occurrence of $12.0 \%$ (95\% CI, 6.1-17.9\%, $n=155)$, compared to $4.2 \%$ (95\% CI $2.9-5.9 \%, n=870$ ) for red squirrels. Proportionally, grey squirrels occurred more often in pine marten scats than red squirrels (Fig. 1. Fisher Exact Test, $p<0.001$ ).

The frequency of occurrence of both squirrel species in pine marten scats varied seasonally in the Northern Ireland samples (Fig. 2, grey squirrels: Pearson's Chi squared, $d f=3$, $X^{2}=13.663, p=0.003$; red squirrels: Pearson's Chi squared, $\left.d f=3, X^{2}=13.915, p=0.009\right)$. Grey squirrels only occurred in pine marten scats during spring and summer, with no evidence of occurrence in autumn or winter. Red squirrels occurred in scats collected in spring, summer and also autumn. Like the grey squirrel, red squirrels did not occur in scats during winter. Frequency of occurrence of grey squirrel in scats did not differ between spring and summer (Fisher Exact Test, $p=1)$. Similarly, there was no difference in the frequency of occurrence of red squirrels between spring and summer (Fisher Exact test, $p=0.458$ ), or autumn (Fisher Exact Test, $p=0.663)$. When the frequency of occurrence 
Table 1 Table showing review of red and grey squirrel frequency of occurrence in the diet of European pine marten published literature throughout the range of the pine marten

\begin{tabular}{|c|c|c|c|c|c|c|}
\hline Country & Habitat & Season & Sample size $(n)$ & $\begin{array}{l}\text { Red squirrel } \\
\text { occurrence } \\
(\%)\end{array}$ & $\begin{array}{l}\text { Grey squirrel } \\
\text { occurrence } \\
(\%)\end{array}$ & Authors \\
\hline Northern Ireland & $\begin{array}{l}\text { Broadleaf, Coniferous } \\
\text { plantation, Coniferous } \\
\text { plantation and heath, } \\
\text { Mixed woodlands }\end{array}$ & All year & 918 & 4.8 & 12.0 & Twining et al. (2019) \\
\hline Republic of Ireland & Broadleaf forest & All year & 387 & 0.4 & $\mathrm{n} / \mathrm{a}$ & $\begin{array}{l}\text { Lynch and McCann } \\
\text { (2007) }\end{array}$ \\
\hline Republic of Ireland & $\begin{array}{l}\text { Unspecified fragmented } \\
\text { forest }\end{array}$ & Spring and Summer & 110 & 5 & 15.6 & Sheehy et al. (2013) \\
\hline Republic of Ireland & $\begin{array}{l}\text { Unspecified fragmented } \\
\text { forest }\end{array}$ & Summer & 252 & 3.1 & $\mathrm{n} / \mathrm{a}$ & O’Meara et al. (2014) \\
\hline Scotland & Coniferous plantation & All year & 2475 & $\mathbf{0}$ & $\mathrm{n} / \mathrm{a}$ & Caryl et al. (2012) \\
\hline Scotland & Coniferous plantation & Spring and Summer & 158 & 0.6 & $\mathrm{n} / \mathrm{a}$ & Grabham et al. (2019) \\
\hline Scotland & $\begin{array}{l}\text { Heath, coniferous } \\
\text { plantation and native } \\
\text { woodland }\end{array}$ & All year & 1304 & $\mathbf{0}$ & $\mathrm{n} / \mathrm{a}$ & Balharry, Unpub. thesis \\
\hline Finland & Boreal forest & Winter & 2198 & 4.4 & $\mathrm{n} / \mathrm{a}$ & $\begin{array}{l}\text { Pulliainen and Ollinmaki } \\
\text { (1996) }\end{array}$ \\
\hline Poland & Old growth deciduous & All year & 1203 & 2.5 & $\mathrm{n} / \mathrm{a}$ & Zalewski (2007) \\
\hline Poland & Old growth deciduous & All year & 1735 & 3.7 & $\mathrm{n} / \mathrm{a}$ & Jedrzejewski et al. (1993) \\
\hline Sweden & Boreal forest & Summer & 144 & 38.0 & $\mathrm{n} / \mathrm{a}$ & Storch et al. (1990) \\
\hline Sweden & Boreal forest & Winter & 144 & 19.0 & $\mathrm{n} / \mathrm{a}$ & Storch et al. (1990) \\
\hline Sweden & Boreal forest & Winter and Summer & 760 & 1.5 & $\mathrm{n} / \mathrm{a}$ & Helldin (2000) \\
\hline Belarus & $\begin{array}{l}\text { Mixed coniferous and } \\
\text { deciduous }\end{array}$ & All year & 1222 & $\mathbf{0}$ & $\mathrm{n} / \mathrm{a}$ & Sidorovich et al. (2005) \\
\hline Russia & Unspecified & Winter and Summer & 171 & 1.7 & $\mathrm{n} / \mathrm{a}$ & Yazan (1970) \\
\hline
\end{tabular}

All references that had data to report are highlighted bold

of the two squirrel species was compared, grey squirrels occurred proportionally more than red squirrels in summer (Fisher Exact Test, $p=0.034$ ), but there was no significant difference in spring (Fisher Exact Test, $p=0.165$ ).

\section{Discussion}

The present report sheds light on the direct interactions of a recovering native European predator, the pine marten on both an invasive species, the grey squirrel and a European native, the red squirrel. In response to the scarcity of records in the literature, we provide new evidence to support pine marten predation on both native and invasive sciurid species. There was a higher proportional occurrence of grey squirrel than red squirrel remains in scats. Thus, we hypothesise and provide evidence in support of a plausible mechanism for the observed decline of grey squirrels (Flaherty and Lawton 2019), whereby a recovering predator population has reversed the direction of the interaction between two congeneric squirrel species (Sheehy and Lawton 2014; Sheehy et al. 2018).

A review of the literature demonstrates that pine martens are opportunistic omnivores with carnivorous tendencies with neither squirrel species being a typically commonly occurring prey item (Helldin 2000; Lynch and McCann 2007; Zalewski 2007; Romaniuk 2018; Twining et al. 2019). Their diet and resource use is dependent on the prey availability and vulnerability (Twining et al. 2019). There are numerous historical examples of concerns raised for pine marten recovery and predation of red squirrels (Pulliainen, 1984; Balharry 1993; Paterson and Skipper 2008). However, investigations into pine marten diet have typically shown red squirrels to be numerically unimportant food item with occurrence in the diet to be generally low (Helldin 2000; Lynch and McCann 2007; Zalewski 2007; O'Meara et al. 2014; Sheehy and Lawton 2014), or absent (Balharry unpublished, Caryl et al. 2012). However, occasional reports of elevated occurrence of red squirrels in the scats of pine martens have been associated with cyclical crashes in microtine populations and noted increases in red squirrel populations (Pulliainen and Ollinmaki 1996; Storch et al. 1990). These 
Table 2 Table showing review of seasonal red and grey squirrel frequency of occurrence in the diet of European pine marten published literature throughout the range of the pine marten

\begin{tabular}{|c|c|c|c|c|}
\hline Season & Country & $\begin{array}{l}\text { Red squirrel } \\
\text { occurrence } \\
(\%)\end{array}$ & $\begin{array}{l}\text { Grey squirrel } \\
\text { occurrence } \\
(\%)\end{array}$ & Authors \\
\hline Autumn & Scotland & $\mathbf{0}$ & $\mathrm{n} / \mathrm{a}$ & Caryl et al. (2012) \\
\hline Autumn & Belarus & $\mathbf{0}$ & $\mathrm{n} / \mathrm{a}$ & Sidorovich et al. (2005) \\
\hline Autumn & Northern Ireland & 1.4 & $\mathbf{0}$ & Twining et al. (2019) \\
\hline Autumn and Winter & Poland & 5.0 & $\mathbf{n} / \mathbf{a}$ & Zalewski (2007) \\
\hline Autumn and Winter & Poland & 7.1 & $\mathrm{n} / \mathrm{a}$ & Jedrzejewski et al. (1993) \\
\hline Spring & Scotland & $\mathbf{0}$ & $\mathrm{n} / \mathrm{a}$ & Caryl et al. (2012) \\
\hline Spring & Poland & 5.6 & $\mathrm{n} / \mathrm{a}$ & Zalewski, 2007 \\
\hline Spring & Belarus & $\mathbf{0}$ & $\mathrm{n} / \mathrm{a}$ & Sidorovich et al. (2005) \\
\hline Spring & Northern Ireland & 6.8 & 14.3 & Twining et al. (2019) \\
\hline Spring and Summer & Scotland & 0.6 & $\mathrm{n} / \mathrm{a}$ & Grabham et al. (2019) \\
\hline Spring and Summer & Republic of Ireland & 5 & 15.6 & Sheehy et al. (2013) \\
\hline Spring and Summer & Poland & 0.8 & $\mathrm{n} / \mathrm{a}$ & Jedrzejewski et al. (1993) \\
\hline Summer & Republic of Ireland & 3.1 & $\mathrm{n} / \mathrm{a}$ & O’Meara et al. (2014) \\
\hline Summer & Scotland & $\mathbf{0}$ & $\mathrm{n} / \mathrm{a}$ & Caryl et al. (2012) \\
\hline Summer & Poland & 0.5 & $\mathrm{n} / \mathrm{a}$ & Zalewski (2007) \\
\hline Summer & Sweden & 0.6 & $\mathrm{n} / \mathrm{a}$ & Helldin (2000) \\
\hline Summer & Belarus & $\mathbf{0}$ & $\mathrm{n} / \mathrm{a}$ & Sidorovich et al. (2005) \\
\hline Summer & Northern Ireland & 13.8 & 22.8 & Twining et al. 2019 \\
\hline Winter & Finland & 4.4 & $\mathrm{n} / \mathrm{a}$ & Pulliainen and Ollinmaki, 1996 \\
\hline Winter & Scotland & $\mathbf{0}$ & $\mathrm{n} / \mathrm{a}$ & Caryl et al. (2012) \\
\hline Winter & Belarus & $\mathbf{0}$ & $\mathrm{n} / \mathrm{a}$ & Sidorovich et al. (2005) \\
\hline Winter & Northern Ireland & 0 & 0 & Twining et al. (2019) \\
\hline Winter & Sweden & 2.4 & $\mathrm{n} / \mathrm{a}$ & Helldin (2000) \\
\hline Winter and Summer & Sweden & 19.0 & $\mathrm{n} / \mathrm{a}$ & Storch et al. (1990) \\
\hline
\end{tabular}

Frequency of occurrence has been split into specific seasons where data available

All references that had data to report are highlighted bold

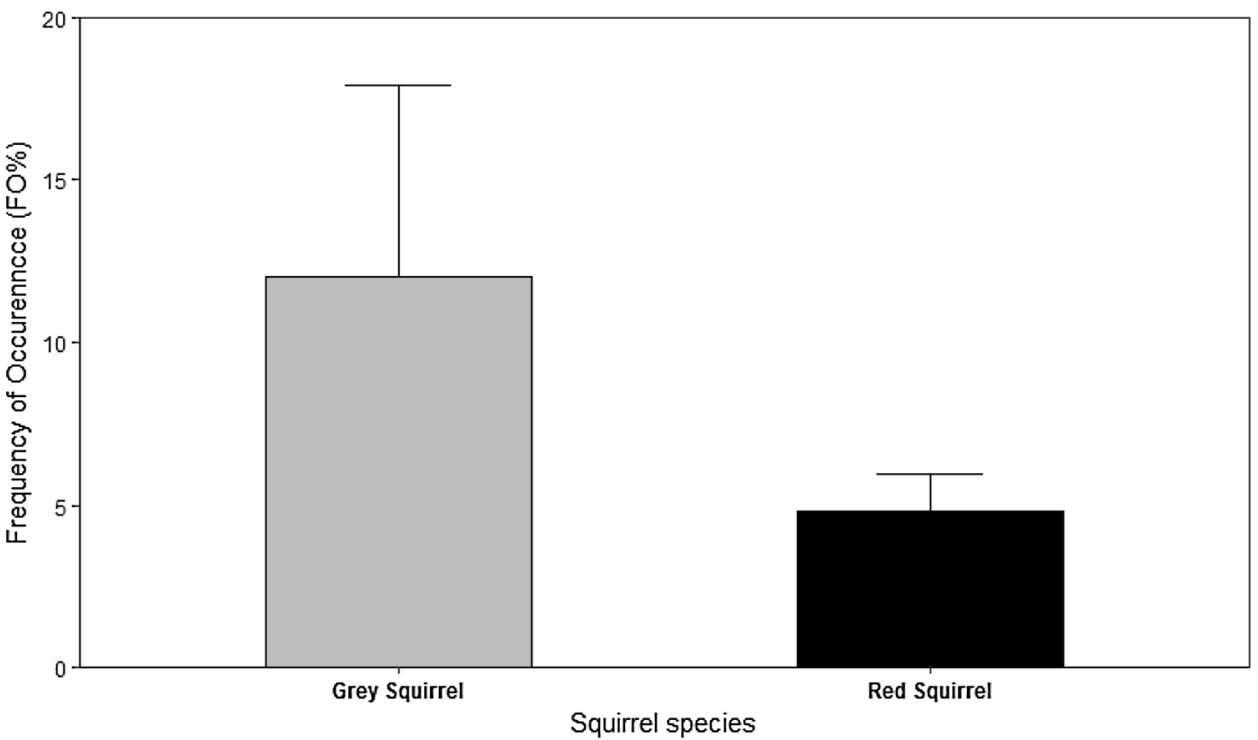

Squirrel species
Fig. 1 Mean (95\% clm) occurrence of grey and red squirrel in scats of the European pine marten (Martes martes) at all sites for red or grey squirrels (Sciurus spp.) Data from Twining et al. (2019) 
Fig. 2 Mean (95\% clm) frequency of occurrence of squirrel species (Sciurus spp.) in pine marten (Martes martes) scats in different seasons Data from Twining et al. (2019)

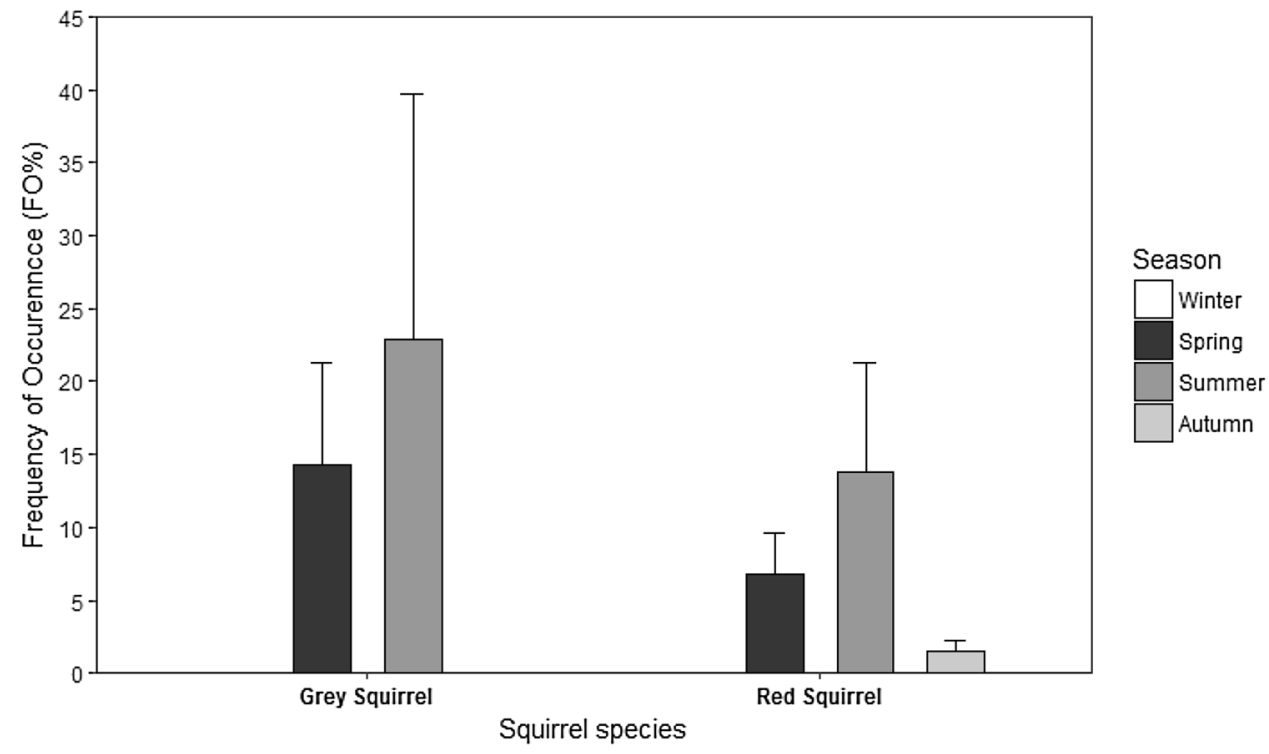

records, along with the elevated predation of red squirrels in two commercial plantation sites in Ireland observed in the data from Twining et al. (2019), suggest that red squirrels serve as an important resource either when highly abundant, or when other key resources are scarce. These observations align with observations that pine martens are highly opportunistic and will target resources that are locally abundant and or vulnerable (Twining et al. 2019).

Despite being a topical and critical question (Sheehy and Lawton 2014; Sheehy et al. 2018; Flaherty and Lawton 2019), there have been limited investigations into the diet of pine martens where they co-occur with grey squirrels. However, when they do co-occur, grey squirrels are a relatively common food item (Sheehy et al. 2013). The lack of studies with grey squirrels present in the environment is likely due to the fact pine marten and grey squirrel ranges do not naturally overlap, and instances in which these species co-occur are highly ephemeral (Flaherty and Lawton 2019). Due to Italy being the only country in mainland Europe where both squirrel species and pine martens occur, Italian dietary studies are of particular interest (Balestrieri et al. 2011; Lombardini et al. 2015). However, neither were used in this review as neither squirrel species is present in Sardinia (Lombardini et al. 2015) and, although the red squirrel was present in at the sites near Garzaia di Valenza, it was not recorded in the diet (Balestrieri et al. 2011). Grey squirrels did not occur at either Italian study site. There is a gap in the literature pertaining to locations where grey squirrels and pine martens co-occur.

We provide much needed data on the occurrence of grey squirrels in the diet within the range of the European pine marten and confirm that pine marten prey upon grey squirrels where they co-occur (Sheehy et al. 2013). We also show that in our study pine martens predate grey squirrels exclusively in spring and summer. This aligns with the reported bi-annual breeding patterns of grey squirrels with litters produced between March and April and a second litter in July and August (Webley and Johnson 1983; Gurnell 1983, 1987). This alignment of increased predation suggests that pine martens may be predating grey squirrels whilst juveniles are present and still restricted to dreys. If pine martens were to take both juveniles and adults, the effect of this predation would likely have a profound effect on recruitment reducing overall population size (Gervasi et al. 2012). Population changes in many mammal species are sensitive to changes in survival (Haydon et al. 1999), whether pine marten predation focusses on juveniles, adults or both, predation in spring and summer could impair recruitment and consequently affect population size. A future study which followed the dynamics of a grey squirrel population closely, combined with monitoring of squirrel boxes with camera traps, while looking at the occurrence of grey squirrels in the scats of the pine marten would provide useful additional insights. Although the age of squirrels predated by pine martens requires direct quantification to make definitive conclusions, a bias towards consumption of juvenile squirrels parallels observations that pine marten significantly increase predation on birds by focussing on altricial juvenile and fledgling birds in spring and summer (Lynch and McCann 2007; Twining et al. 2018). It is possible that predation of grey squirrels in dreys during spring and summer is a byproduct of the observed switch to more arboreal foraging targeting bird nests observed during these months (Twining et al. 2019).

The overall frequency of occurrence of grey squirrel remains in pine marten scats in the present study was similar to Sheehy and Lawton (2014). The latter had reservations due to low sample size but sample size here $(n=155)$ is less of 
a concern. Sample size of pine marten scats in red squirrel areas of occurrence was much higher $(n=877)$. This disparity reflects the particular biogeographical circumstances in Ireland where grey squirrels and pine marten, increasingly, do not cooccur (Sheehy and Lawton 2014; Flaherty and Lawton 2019). Despite having similar reproductive cycles to grey squirrels and sharing similar seasonal peaks of presence in the diet of pine martens in spring and summer, red squirrels have a lower overall frequency of occurrence in pine marten scats than grey squirrels. Interspecific disparities in frequency of occurrence in the diet of similar prey species, however, may reflect differences in prey density, body size and behaviour (Toscano et al. 2010; Lucas and Rosenheim 2011; Tucker and Rogers 2014). This prevents a definitive conclusion explaining the more frequent occurrence in pine marten scats of greys than red squirrels. Differences in species ecology, with red squirrels living at much lower densities than greys $(0.3-1.5 /$ ha vs. $2-16 /$ ha; Gurnell 1987), making them less available as a food item in the environment, has been suggested as a potential basis for higher predation rates amongst grey squirrels (Sheehy and Lawton 2014). The evidence that exposure to pine martens reverses the outcome of red-grey squirrel competition at landscape scales throughout Ireland and Scotland, where densities of species vary greatly, suggests that density of squirrel populations does not greatly affect the underlying mechanism of this process. The recent research demonstrating that grey squirrels do not possess anti-predator behaviours in response to the pine marten, while red squirrels show very clear behavioural responses and avoidance may provide explanation of the observed higher occurrence of grey squirrels in the diet of pine marten (Twining et al. 2020).

In conclusion, although red squirrel predation by the European pine marten is typically low, there are specific situations when higher predation levels occur. Additionally, where grey squirrels and pine martens co-occur, occurrence of grey squirrels in the diet of the pine marten is significantly higher than that of red squirrels. Thus, we hypothesise that, due to the absence of anti-predator behaviours (Twining et al. 2020), the invasive grey squirrel is predated by pine marten proportionally more than the red squirrel leading to a gradual decline in grey squirrel abundance and distribution. Although not conclusive, we provide a plausible mechanism for the established reversal of native red squirrel by invasive grey squirrels in the presence of pine martens in Ireland and Britain (Sheehy and Lawton 2014; Sheehy et al. 2018; Flaherty and Lawton 2019).

Acknowledgements We would like to thank the People's Trust of Endangered Species for providing funding for the project, and the Department for the Economy NI for providing funding for the studentship. Thanks also to Forest Service Northern Ireland for access permits, and private landowners for access to sites. We would like to thank our two anonymous reviewers and subject editor Raquel Monclús who provided us with constructive criticisms allowing us to improve our manuscript.

Open Access This article is licensed under a Creative Commons Attribution 4.0 International License, which permits use, sharing, adaptation, distribution and reproduction in any medium or format, as long as you give appropriate credit to the original author(s) and the source, provide a link to the Creative Commons licence, and indicate if changes were made. The images or other third party material in this article are included in the article's Creative Commons licence, unless indicated otherwise in a credit line to the material. If material is not included in the article's Creative Commons licence and your intended use is not permitted by statutory regulation or exceeds the permitted use, you will need to obtain permission directly from the copyright holder. To view a copy of this licence, visit http://creativecommons.org/licenses/by/4.0/.

\section{References}

Balharry D (1993) Factors affecting the distribution and population density of Pine Martens (Martes martes) in Scotland. A thesis submitted for the degree of $\mathrm{PhD}$ at the University of Aberdeen, Scotland

Balestrieri A, Remonti L, Ruiz-González A, Vergara M, Capelli E, Gómez-Moliner BJ, Prigioni C (2011) Food habits of genetically identified pine marten (Martes martes) expanding in agricultural lowlands (NW Italy). Acta Theriol 56:199-207

Barr JJF, Lurz PWW, Shirley MDF, Rushton SP (2002) Evaluation of immunocontraception as a publicly acceptable form of vertebrate pest species control: the introduced grey squirrel in Britain as an example. Environ Manag 30:342-351

Bertolino S, Montezemolo NC, Preatoni DG, Wauters LA, Martinoli A (2014) A grey future for Europe: Sciurus carolinensis is replacing native red squirrels in Italy. Biol Invasions 16:53-62

Caryl FM, Raynor R, Quine CP, Park KJ (2012) The seasonal diet of British pine marten determined from genetically identified scats. J Zool 288:252-259

Charles H, Dukes JS (2008) Impacts of invasive species on ecosystem services. Biol Invasions 193:217-237

Cooke BD, Fenner F (2002) Rabbit haemorrhagic disease and the biological control of wild rabbits, Oryctolagus cuniculus, in Australia and New Zealand. Wildl Res 29(6):689-706

Flaherty M, Lawton C (2019) The regional demise of a non-native invasive species: the decline of grey squirrels in Ireland. Biol Invasions 21:2401-2416

Gervasi V, Nilsen EB, Sand H et al (2012) Predicting the potential demographic impact of predators on their prey: a comparative analysis of two carnivore-ungulate systems in Scandinavia. J Anim Ecol 81(2):443-454

Genovesi P, Bertolini S (2001) Human dimension aspects in invasive alien species issues: the case of the failure of the grey squirrel eradication project in Italy. In book: the great reshuffling: human dimensions of Invasive Alien Species, Publisher: IUCN, Editor: McNeely J, pp 113-119

Grabham A, Ventress G, Hayward MW (2019) The diet of denning female European pine martens (Martes martes) in Galloway Forest District, South West Scotland, Great Britain. Mamm Res 64:87-97

Gurnell J (1983) Squirrel numbers and the abundance of tree seeds. Mammal Rev 13:133-148

Gurnell J (1987) The natural history of squirrels. Christopher Helm, London 
Gurnell J, Wauters LA, Lurz PWW, Tosi G (2004) Alien species and interspecific competition: effects of introduced eastern grey squirrels on red squirrel population dynamics. J Anim Ecol 73:26-35

Haydon D, Gillis E, Stefan CI, Krebs CJ (1999) Biases in the estimation of the demographic parameters of a snowshoe hare population. J Anim Ecol 68:501-512

Hays W, Conant S (2007) Biology and impacts of Pacific Island invasive species. 1. A Worldwide review of effects of the Small Indian Mongoose, Herpestes javanicus (Carnivora: Herpestidae). Pac Sci 61(1):3-16

Helldin JO (2000) Seasonal diet of pine marten Martes martes in southern boreal Sweden. Acta Theriol 45:409-420

Hewson CM, Fuller RJ (2003) Impacts of grey squirrels on woodland birds: an important predator of eggs and young? BTO Research Report no. 328, British Trust for Ornithology. Thetford, UK

Invasive Species Advisory Committee (2006) Invasive species definition clarification and Guidance White Paper. The National Invasive Species Council, Digital Commons, Lincoln, p 11

Jedrzejewski W, Zalewski A, Jedrzejewska B (1993) Foraging by pine marten (Martes martes) in relation to food resources in Bialowieza National Park, Poland. Theriol 38(4):405-426

Kelly J, Tosh DG, Dale K, Jackson A (2013) The economic cost of invasive and non-native species in Ireland and Northern Ireland. A report prepared for NIEA and NPWS by Invasive Species Ireland

Kettunen M, Genovesi P, Gollasch S, Pagad S, Starfinger, Brink U, Shine CP (2009) Technical support to EU strategy on invasive species (IAS)ùAssessment of the impacts of IAS in Europe and the EU. Final report for the European Commission. Institute for European Environmental Policy (IEEP). Brussels, Belgium

Klare U, Kamler JF, Macdonald DW (2011) A comparison and critique of different scat-analysis methods for determining carnivore diet. Mamm Rev 41:294-312

Lindquist DA, Abusowa M, Hall MJR (1992) The New World screwworm fly in Libya: a review of its introduction and eradication. Med Vet Entomol 6(1):2-8

Lioy S, Marsan A, Balduzzi A, Wauters LA, Martinoli A, Bertolino $S$ (2019) The management of the introduced grey squirrel seen through the eyes of the media. Biol Invasions 21:3723-3733

Lloyd HG (1968) Past and present distribution of red and grey squirrels. Mamm Rev 13:69-80

Lombardini M, Murru M, Repossi A, Cinerari CE, Vidus Rosin A, Mazzoleni L, Meriggi A (2015) Spring diet of the pine marten in Sardinia, Italy. Anim Biodivers Conserv 38(2):183-190

Lucas E, Rosenheim JA (2011) Influence of extraguild prey density on intraguild predation by heteropteran predators: a review of the evidence and a case study. Biol Control 59:61-67

Lynch AB, McCann Y (2007) The diet of the pine marten (Martes martes) in Killarney National Park. Biol Environ Proc R Ir Acad 107:67-76

Manchester SJ, Bullock JM (2001) The impacts of non-native species on UK biodiversity and the effectiveness of control. J Appl Ecol 37(5):845-864

Mayle BA, Broome AC (2013) Changes in the impact and control of an invasive alien: the grey squirrel (Sciurus carolinensis) in Great Britain, as determined from regional surveys. Pest Manag Sci 69:323-333

Menge BA, Sutherland JP (1976) Species diversity gradients: synthesis of the roles of predation, competition and temporal heterogeneity. Am Nat 110:351-369

Newson S, Leech DI, Hewson CM, Crick HQP, Grice P (2010) Potential impact of grey squirrels Sciurus carolinensis on woodland bird populations in England. J Ornithol 151(1):211-218

O'Donnell CFJ, Weston KA, Monks JM (2017) Impacts of introduced Mammalian predators on New Zealand's Alpine Fauna. N Z J Ecol 41(1):1-22
O’Meara D, Sheehy E, Turner P, O'Mahony D, Harrington A, Denman H, Lawton C, MacPherson J, O'Reilly C (2014) Non-invasive multi-species monitoring: real-time PCR detection of small mammal and squirrel prey DNA in pine marten (Martes martes) scats. Acta Theriol 59:111-117

O'Reilly C, Staham M, Mullins J, Turner PD, O’Mahony D (2007) Efficient species identification of pine marten (Martes martes) and red fox (Vulpes vulpes) scats using a $5^{\prime}$ nuclease real-time PCR assay. Conserv Genet 9:735-738

Paterson WD, Skipper G (2008) The diet of pine martens (Martes martes) with reference to squirrel predation in Loch Lomond and the Trossachs National Park. University of Glasgow, Glasgow, Scotland. BSc dissertation

Pimental D, Zach L, Luniga R, Morrison D (2000) Environmental and economic costs of nonindigenous species in the United States. Biosciences 50(1):53-65

Pulliainen E (1984) Use of the home range by pine martens (Martes martes). Acta Zool Fennica 171:271-274

Pulliainen E, Ollinmaki P (1996) A long term study of the winter food niche of the pine marten (Martes martes) in northern boreal Finland. Acta Theriol 41:337-352

R Core Team (2014) R: a language and environment for statistical computing. R Foundation for Statistical Computing, Vienna, Austria. http://www.R-project.org/

Romaniuk A (2018) Shape variation of Palearctic mustelids (Carnivora: Mustelidae) mandible is affected both by evolutionary history and ecological preference. Hystrix 29(1):87-94

Romeo C, Ferrari N, Lanfranchi P, Saino N, Santicchia F, Martinoli A, Wauters LA (2015) Biodiversity threats from outside to inside: effects of alien grey squirrel (Sciurus carolinensis) on helminth community of native red squirrel (Sciurus vulgaris). Parasitol Res. https://doi.org/10.1007/s00436-015-4466-3

Rushton SP, Lurz PWW, Gurnell J, Nettleton P, Bruemmer C, Shirley MDF, Sainsbury AW (2006) Disease threats posed by alien species: the role of a poxvirus in the decline of the native red squirrel in Britain. Epidemiol Infect 134(3):521-533

Schuchert P, Shuttleworth CM, McInnes CJ, Everest DJ, Rushton SP (2014) Landscape scale impacts of culling upon a European grey squirrel population: can trapping reduce population size and decrease the threat of squirrelpox virus infection for the native red squirrel? Biol Invasions 16(11):2381-2391

Sheehy E, Lawton C (2014) Population crash in an invasive species following the recovery of a native predator: the case of the American grey squirrel and the European pine marten in Ireland. Biodivers Conserv 23:753-774

Sheehy E, O'Meara D, O'Reilly C, Smart A, Lawton C (2013) A noninvasive approach to determining pine marten abundance and predation. Eur J Wildl Res 60:223-236

Sheehy E, Sutherland C, O'Reilly C, Lambin X (2018) The enemy of my enemy is my friend: native pine marten recovery reverses the decline of the red squirrel by suppressing grey squirrel populations. Proc R Soc B 285:20172603

Shine R (2010) The ecological impact of invasive cane toads (Bufo marinus) in Australia. Q Rev Biol 85(3):253-291

Sidorovich VE, Krasko DA, Dyman AA (2005) Landscape related differences in diet, food supply and distribution pattern of the pine marten, Martes martes in the transitional mixed forest of northern Belarus. Folia Zool 54(1-2):39-52

Simberloff D, Stiling P (1996) Risks of species introduced for biological control. Biol Cons 78(1-2): 185-192

Storch I, Lindstrom E, De Jounge J (1990) Diet and habitat selection of the pine marten in relation to competition with the red fox. Acta Theriol 35:311-320

Teerink BJ (1991) Hair of West-European mammals. Cambridge University Press, Cambridge, p 236 
Tompkins DM, White AR, Boots M (2003) Ecological replacement of native red squirrels by invasive greys driven by disease. Ecol Lett 6(3):189-196, 16th -22nd August

Tosh D (2015) Monitoring small carnivore populations using citizen scientists. 7th European Congress of Mammalogy, Stockholm, Sweden

Toscano BJ, Fodrie JF, Madsen SL, Powers SP (2010) Multiple prey effects: agonistic behaviors between prey species enhances consumption by their shared predator. J Exp Mar Biol Ecol 385:59-65

Tucker MA, Rogers TL (2014) Examining predator-prey body size, trophic level and body mass across marine and terrestrial mammals. Proc R Soc B Biol Sci 281(1797):20142103

Twining JP, Birks JD, Martin J, Tosh DG (2018) Using den boxes to explore food caching by the European pine marten. Mamm Commun 4:1-6

Twining JP, Montgomery WI, Scantlebury DM, Marks N, Tosh DG (2019) Seasonal, habitat and geographical effects on the diet of a recovering native predator: the European pine marten (Martes martes). Eur J Wildl Res 65:51. https://doi.org/10.1007/s1034 4-019-1289-Z

Twining JP, Montomgery WI, Price L, Kunc HP, Tosh DG (2020) Native and invasive squirrels show different behavioural responses to scent of a shared native predator. R Soc Open Sci. https://doi. org/10.1098/rsos.191841

Velli E, Fabbri E, Galaverni M, Mattucci F, Mattioli L, Molinari L, Caniglia R (2019) Ethanol versus swabs: what is a better tool to preserve faecal samples for non-invasive genetic analyses? Hystrix Ital J Mammol 30(1):24-29
Wauters LA, Gurnell J (1999) The mechanism of replacement of red squirrels by grey squirrels: a test of the interference competition hypothesis. Ethology 105:1053-1071

Wauters LA, Mazzamuto MV, Santicchia F, Dongen SV, Preatoni DG, Martinoli A (2019) Interspecific competition affects the expression of personality-traits in natural populations. Sci Rep 9:11189

Webley GE, Johnson E (1983) Reproductive physiology of the Grey squirrel (Sciurus carolinenis). Mammal Rev 13:149-154

Witmer GW, Eisemann JD, Howald G (2007) The use of rodenticides for conservation efforts. USDA National Wildlife Research Center - Staff Publications 780: https://digitalcommons.unl.edu/icwdm usdanwrc/780

Yazan YP (1970) Relations between the marten (Martes martes), sable (Martes zibellina), and kidas (Martes martes x Martes zibellinu) as predators and squirrel (Sciurus vulgaris) as a prey. Trans Int Congr Game Biol 9:530-538

Zalewski J (2007) Does size dimorphism reduce competition between sexes? The diet of male and female Pine Martens at local and wider geographical scales. Acta Theriol 52(3):237-250

Publisher's Note Springer Nature remains neutral with regard to jurisdictional claims in published maps and institutional affiliation'. 